Socretr, in the liberal view, cultivates science as an organism of ideas which powerfully attracts the minds of intelligent people, and also to increase the store of knowledge available for practical application. This position of science in society is a significant example of the principles of liberty, being indeed merely a special feature of the position of thought in society. Freedom is not only possible but also a social necessity when we admit that the realm of thought possesses its own life. Prof. Polanyi dissents from Prof. Bernal's desire to put science into the consciously organized service of human welfare, arguing that the now attitude leads to the approval of oppression of intellectual liberty, if it is perpetrated only in pursuit of approved political aims. Prof. Polanyi is on firm ground in criticizing a somewhat propagandist attitude in regard to Soviet Russia, but his sincere plea for the re-establishment of man's right to pursue truth regardless of social interests would have more reality if he would recognize the present lopsidedness of scientific development. The reorientation of scientific effort for which so many scientific workers are calling involves no threat to fundamental research, which, indeed, it is desired to instigate in fields at present neglected.

\section{Weather Reports in the United States}

According to a report which has been issued by Science Service, the United States Weather Bureau is making the experiment of having both aviation forecasts and genoral forecasts not specially suited to the requirements of aviation made by a single staff, in the case of the new district office of the Weather Bureau at Kansas City airport. Up to now, aviation forecasts have been made by special staffs at airports, while the other forecasts were made independently at Weather Bureau offices located in the different towns. If this experiment, which began on October 1, proves successful, it is intended to extend it to other stations of the Weather Bureau. The Kansas City district office programme includes also a new feature that has recently been introduced at Washington and Baltimore and which has proved very popular, namely, a 'breakfast time' broadcast forecast. It is expected that this will bo extended to many other American cities in the near future. It is not stated what time is taken as 'breakfast time' for the purpose of these broadcasts, but presumably it is too late to make the forecasts meet the requirements of farmers, who must arrange what work shall be done during the day at an early hour and could only take account of correspondingly early forecasts. There was before the War a demand by British farmers for such 'prebreakfast' forecasts; but an obstacle in the way of their realization is that an hour or two must elapse between the taking of the observations on which the forecasts must be based and the time at which they are made, to allow the information to be collected, decoded, charted and critically examined, and a very largo number of observers would have to begin their day's work at about 4 a.m.

\section{Penetration of the Skin by Heat}

IN a paper entitled "Tho Penetration of Rays through the Skin, and Radiant Energy for the Treatment of Wounds", read before the Royal Society of Arts on November 22, Sir Leonard Hill gave a useful review of our knowledge of the extent to which luminous, thermal and other radiations can penetrate the skin. He also referred to some of his own recent work on the differences in the penetrating power of heat radiation according to the nature of its source. Experiments on the production of artificial fever by means of short-wave oscillators show that the body temperature can be raised to $105^{\circ}-106^{\circ} \mathrm{F}$. in an hour or so.

VITH what some of his listeners may have thought a curious irrelovance to the subject, Sir Leonard delivered himself of a judgment about radium treat. ment, to wit "The world would, I think, be little the worse off if all the radium in the country now buried for security from bombing in deep holes, remained therein. Very big monetary influences will cry out against this". The question may well be asked whether Sir Leonard really belioves that these monetary influences determine the practice of radium therapy in Great Britain. About 15,000 patients received such treatment in 1938. Are the results of so little value to cancer and other patients that Sir Leonard's advice should bo taken on this subject ? The Cancer Act is the country's reply to such a question.

\section{Quantitative Estimates of Sensory Events}

Tine final report of the committee appointed to consider and report upon the possibility of quantitative estimates of sensory events has appeared (Sections A and J, British Association, Dundee, 1939). This committeo was appointed in 1932 after Sections $A$ and $J$ of the British Association had held a joint session dealing with the problem. It has been reappointed each year since. In 1938 a long interim report was presented containing: (a) a historical statement ; a summary of recent experimental work ; (b) a statement arguing that sensation intensities are not measurable; (c) various notes on this statement; (d) a statement arguing that sensation intensities are measurable. A subcommittee was appointed to consider whether the views put forward wero really irreconcilable. This subcommitteo presented a draft report to the British Association this year. It now seems that agreement is impossible. This is scarcely surprising when there is disagreement as to the meaning of 'measurement'. If it is postulated that this term must be limited to its applicability in physics, then this would rule out the use of the word in relation to much psychological work. Two extreme views hold the field, and a close examination of these views by a member who holds an intermediate view leads to the conclusion that they cannot be reconciled. The report therefore consists of the views of individual members. The discussion is of value, even apart from the data here presented, as illustrating some of the difficulties inherent in such problems. 